\title{
Cultivation of dandelion (Taraxacum erythropodium) on coastal saline land based on the control of salinity and fertilizer
}

\author{
Zhe Wu, Zhizhong Xue, Haishan Li, Xiaodong Zhang, \\ Xiuping Wang, Xuelin Lu*
}

Institute of Coastal Agriculture, Hebei Academy of Agriculture and Forestry Sciences 63 Binhai Street, Caofeidian, Tangshan 063299, China

\begin{abstract}
Dandelion (Taraxacum spp.) is a widely distributed weed; in China, however, dandelion has been considered to be a kind of medicinal and edible vegetable in recent years. This transition from weed to vegetable requires corresponding cultivation and management. Thus, the production of dandelion on saline land was conducted based on the evaluation of dandelion salt tolerance. Low soil salt content $(<0.3 \%)$ did not significantly affect dandelion growth, and the salt tolerance threshold of dandelion ranged from $0.4 \%$ to $0.43 \%$ according to the correlation between salt content and morphological and physiological parameters, which was for guiding the preparation of saline land for dandelion field cultivation. Different fertilizer treatments significantly affected the leaf yield of dandelion, and the maximum fresh leaf yield of $\sim 10.5 \mathrm{t} \mathrm{ha}^{-1}$ was obtained when urea was applied in batches at a ratio of 2:2:1 in the sowing, seedling and flowering stages, respectively. This research provided the theoretical and technical support for the cultivation on saline land, laying the foundation for further study of quality control for the cultivation of dandelion on saline land.
\end{abstract}

Key words: crop production, field control, herbal vegetable, salt tolerance identification, saline land treatment

\begin{abstract}
Abbreviations:
ADW - aboveground dry weight, Chl - total chlorophyll, DLY - dry leaf yield, FLY - fresh leaf yield, LL - leaf length, LN - leaf number, LW - leaf width, MP - membrane permeability, MDA - malonaldehyde, Pro - proline, PW - plant width, SC - salt content, SP - soluble protein, SR - survival rate, UDW - underground dry weight
\end{abstract}

\section{INTRODUCTION}

The Hebei province, China, has about 780,000 ha of saline-alkaline land, accounting for $10.4 \%$ of cultivated land. Low land quality leads to scattered salt-tolerant weeds (Suaeda spp.) and low land productivity. Especially in the area where this experiment was located, the soil is mainly composed of muddy saline-silt with a high salt content of even more than $1.2 \%$, which, coupled with less rainfall, leads to a large area of barren land ( $\mathrm{Li}$ et al., 2016). The planting of economic plants with strong salt tolerance can effectively utilize these lands and have a better effect on ecological restoration.

Dandelion is a widespread weed and has strong resistance to environmental adversities. It is a traditional Chinese herbal medicine which is rich in polysaccharides, phenolic acids, sterols

\footnotetext{
*Corresponding author. 
and other substances, and has sterilization, antiinflammatory, anti-oxidation and immunity enhancement functions (Katrin et al., 2010; Iddrisu et al., 2016). With the improvement of health awareness, in recent years, dandelion has gradually become a new trend as a medicinal and edible vegetable in China, altering the wild occurrence of dandelion to artificial cultivation (Kuusi et al., 1984; Wang et al., 2017; Jiang et al., 2018). In recent years, some studies have been carried out on the cultivation practices for dandelion rubber and root production for rubber resource reserve and medicinal use (Arias et al., 2016; Kreuzberger et al., 2016). However, there are still very few cultivation experiences for the purpose of food production on saline-alkaline land.

Thus, in order to know the growth and leaf yield of dandelion under cultivation on saline land, salt tolerance evaluation work was conducted to guide the field cultivation on saline land according to the salt tolerance threshold of dandelion. The ultimate purpose of this research was to provide ideas and experiences for the popularization of dandelion cultivation on saline-alkaline land. Our evaluation work also provided references for salt-tolerance identification of short- and shallow-root crops.

\section{MATERIAL AND METHODS}

\section{Site description}

The experiment was carried out on heavy saline land in the Industrial Zone of Caofeidian District, Tangshan, China (north China, $39.23^{\circ} \mathrm{N}, 118.57^{\circ} \mathrm{E}$ / $\left.39^{\circ} 13^{\prime} \mathrm{N}, 118^{\circ} 34^{\prime} \mathrm{E}\right)$. The average soil texture in the $0-60 \mathrm{~cm}$ soil layer is silt, where $0.7 \%$ of the particles are less than $2 \mu \mathrm{m}, 87 \%$ are $2-50 \mu \mathrm{m}$, and $12 \%$ are larger than $50 \mu \mathrm{m}$. The electrical conductivities of the saturated soil extracts range from 12.5 to $24.7 \mathrm{dS} / \mathrm{m}$, the total soil salt content is $0.3-1.8 \%$ and $\mathrm{pH} 7.5-7.7$; the soil bulk density is $1.46-1.75 \mathrm{~g} \mathrm{~cm}^{3}$, according to the method described by the authors (Xiuping et al., 2019). The soil contains organic matter $-1.43 \%$, available nitrogen - $62.3 \mathrm{mg} \mathrm{kg}{ }^{-1}, \mathrm{P}_{2} \mathrm{O}_{5}-27.1 \mathrm{mg} \mathrm{kg}^{-1}$ and $\mathrm{K}_{2} \mathrm{O}-$ $232 \mathrm{mg} \mathrm{kg}^{-1}$, according to the method described in our previously published paper (Xuelin et al., 2019). The average annual precipitation is approximately $600 \mathrm{~mm}$ and the main irrigation water is from the Lun river.

\section{Dandelion resource}

'Daye dandelion', selected from wild dandelion Taraxacum erythropodium by salt-tolerant mutant breeding (Zhang et al., 2008; Liu et al., 2017), was used as the experimental object and cultivar to be popularized in the future. This cultivar is rich in beneficial components such as flavonoids, selenium and chlorogenic acid, and exhibits strong growth, broad leaves and good commercial quality (Liu et al., 2017). To highlight the advantages of this cultivar, five other dandelion species from different habitats were planted at the same time in the field under the same cultivation conditions.

\section{Saline treatment and evaluation}

Dandelion salt tolerance identification was conducted in August to October 2017 and repeated in April to June 2018. Saline soils with a total salt content of $1.78 \%$ and $0.1 \%$ were separately dried and sieved, and uniformly mixed to obtain soils with the salt content of $0.1 \%, 0.2 \%, 0.3 \%, 0.4 \%$, $0.5 \%, 0.7 \%, 0.9 \%, 1.1 \%$, and $1.2 \%$, to serve as different treatments. The soils were then used to fill flower pots, which were placed $2 \mathrm{~cm}$ above a fresh water pool. The salt content of $0.1 \%$ was the control treatment (Fig. 1). Each treatment was a set of 6 repetitions, and randomly distributed. The dandelion plants were transplanted into the pots when the seedling had 2 leaves. All of the above identification processes were carried out in an open rain-proof shelter without artificial climate control. The morphological and physiological parameters were recorded after 60 days, including survival rate, leaf length, leaf width, leaf number, aboveground dry biomass weight, underground dry biomass weight, $\mathrm{K}^{+} / \mathrm{Na}^{+}$rate, plasma membrane permeability, total chlorophyll, MDA, proline and soluble protein. The specific methods of determining the above parameters are given in the references (Clemens, 2017; Liu et al., 2017; Eggert et al., 2018).

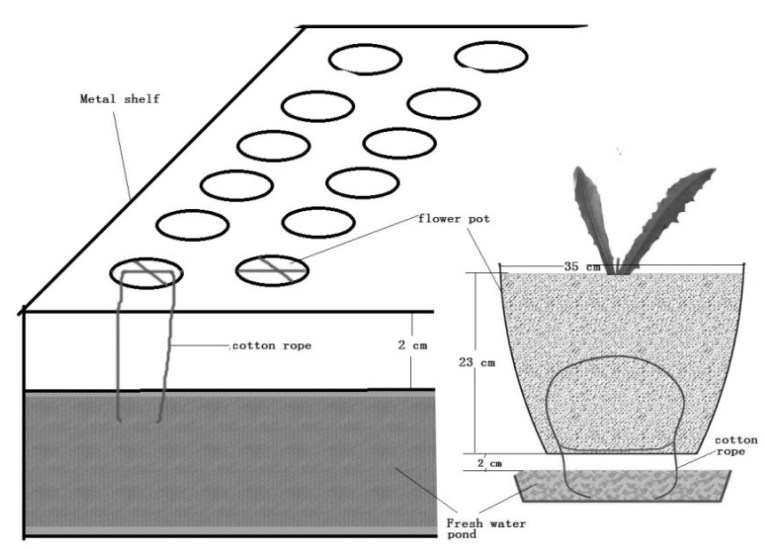

Figure 1. Saline treatment and salt tolerance identification 


\section{Guiding for field preparation and dandelion cultivation}

According to the salt tolerance threshold obtained from the saline treatment test, the total soil salt content was less than $0.3 \%$, which was classified as mild saline land without salt washing; when the content was greater than $0.4 \%$, the total soil salt content within the $30 \mathrm{~cm}$ tillage layer should be reduced to a lower value, creating favourable soil conditions for dandelion seedling emergence. The experimental area was $667 \mathrm{~m}^{2}$, the total soil salt content ranged from $0.4 \%$ to $0.6 \%$, and the irrigation quota was $50 \mathrm{~m}^{3}$ for washing salts. According to the experimental records and operation experience, when the soil salt content was greater than $0.6 \%$, the recommended amount of irrigation was 900 $1350 \mathrm{~m}^{3} \mathrm{ha}^{-1}$. After irrigation, the water layer was kept at $5 \mathrm{~cm}$ for 3 days before sowing dandelions. The dandelions were irrigated by sprinkling with $13 \mathrm{~m}^{3}$ of water until the harvest stage.

Dandelions were grown in the spring (AprilJune) and again in the summer (July-October) in 2018, and the final leaf yields were averaged over the two seasons. The land was furrowed, with a row spacing of $30 \mathrm{~cm}$ and plant spacing of $15 \mathrm{~cm}$, and fertilized with $225 \mathrm{~kg} \mathrm{KH}_{2} \mathrm{PO}_{4} \mathrm{ha}^{-1}$ and $3000 \mathrm{~kg}$ cattle manure ha- ${ }^{-1}$. Urea at five levels of 0 , $3.6 \mathrm{~kg}, 7.2 \mathrm{~kg}, 10.8 \mathrm{~kg}$ and $14.4 \mathrm{~kg}$ was applied as five treatments at the sowing stage (15 April and 10 July), seedling stage (14 May and 11 August) and flowering period (9 June and 4 September), respectively. Each treatment with urea was a set of three repetitions. The leaf yield and growth performance were recorded at the harvest stage (25 June and 20 October).

\section{Data analysis}

Each parameter from the experiment of salt tolerance identification was represented by 25 measurement values which were used for data significance analysis and correlation coefficient analysis. Correlation coefficients among all the parameters and salt content were determined to find the best-fit correlation function. The salt tolerance threshold was calculated from the function formula, namely it was equal to the soil salt content when the independent variable changed to half or double of that in the control treatment, in which the soil salt content was $0.1 \%$ (Liu et al., 2017). Each parameter from the field experiment was represented by 75 measurement values which were used for data significance analysis. Duncan's (D) significant difference test and correlation analysis were performed using SPSS 16.0. The statistical analysis and regression analysis were performed using Excel 2017. The results were calculated as mean \pm standard error, and the images were created with Origin 8.0 software.

\section{RESULTS}

\section{Growth performance under increasing soil salt content}

Dandelion growth significantly declined with the increase in soil salt content and all the growth characteristics showed a downward trend (Figs 2 and 3). The average dry leaf yield per plant decreased significantly from $2.75 \mathrm{~g}$ in the treatment with $0.1 \%$ soil salt to $0.08 \mathrm{~g}$ in that with $1.2 \%$ soil salt. When the salt content was between $0.3 \%$ and $0.4 \%$, the trend of all the parameters started to decline rapidly. When the salt content exceeded
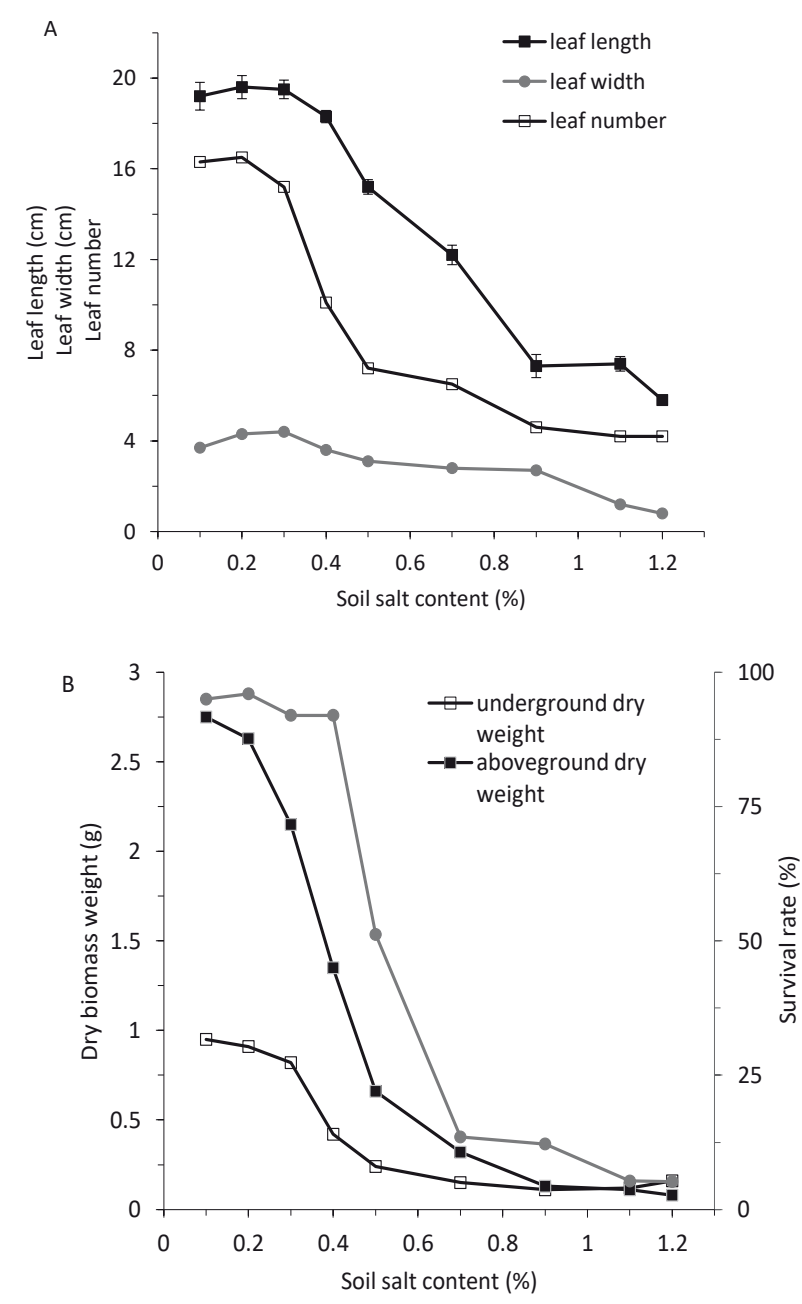

Figure 2. Morphological parameters of T. erythropodium under increasing soil salt content. Six repetitions with 25 measurement values for each treatment were used to calculate the means 


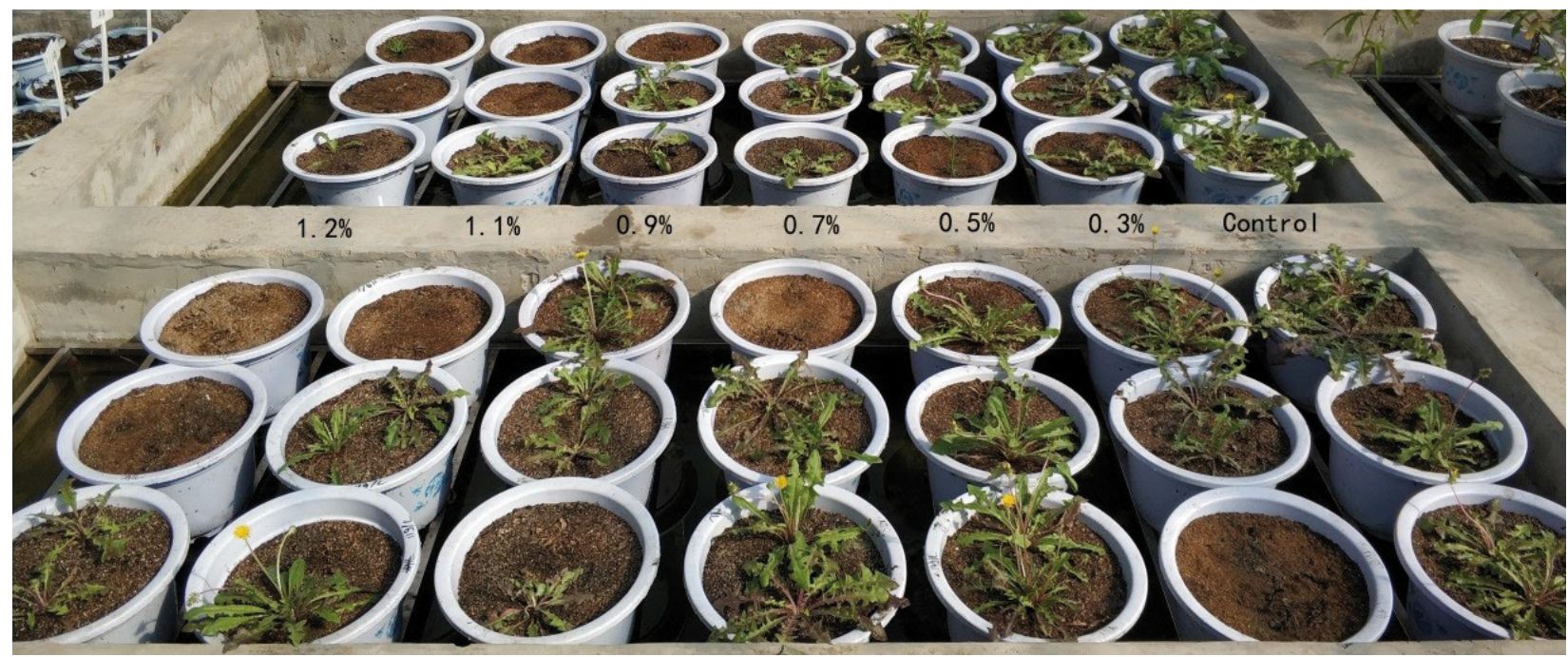

Figure 3. Dandelion growth under increasing soil salt content at the flowering stage (28 Aug 2018)

$0.7 \%$, this declining trend weakened. These results showed that a high soil salt content $(>0.7 \%)$ significantly inhibited the growth of dandelion. Through the response of these parameters to salt content, the effectiveness of soil salt content in terms of its effect on the growth of dandelion was as follows: leaf length $>$ survival rate $>$ leaf width $>$ leaf number $>$ aboveground dry weight $>$ underground dry weight (Tab. 1).

\section{Variation of physiological parameters under increasing soil salt content}

The MDA and proline contents and leaf plasmamembrane permeability increased with soil salt content, while the amounts of soluble protein, total chlorophyll and the $\mathrm{Na}^{+} / \mathrm{K}^{+}$rate in the leaves were decreased (Fig. 4). When the salt content was $>0.4 \%$, MDA, proline and leaf plasma-membrane permeability increased significantly, indicating that dandelion responded quickly to the increase in soil salt content. When the salt content was $>0.8 \%$, these parameters tended to be stable or even decreased, indicating that the effect of high soil salt content had exceeded dandelion's self-regulatory capacity. Similarly, when the salt content was greater than $0.4 \%$, the amounts of soluble protein, total chlorophyll and the $\mathrm{K}^{+} / \mathrm{Na}^{+}$rate decreased significantly and tended to be stable.

\section{Determination of salt tolerance threshold}

The correlations among all the parameters were analyzed (Tab. 1). The correlation coefficients for

Table 1. Correlation coefficients among all the parameters for dandelion salt tolerance threshold determination

\begin{tabular}{|c|c|c|c|c|c|c|c|c|c|c|c|c|c|}
\hline & $\mathrm{SC}$ & LL & LW & LN & SR & ADW & UDW & MDA & SP & Pro & Chl & MP & $\mathrm{K}^{+} / \mathrm{Na}^{+}$ \\
\hline $\mathrm{SC}$ & 1 & & & & & & & & & & & & \\
\hline LL & -0.97 & 1 & & & & & & & & & & & \\
\hline LW & -0.94 & 0.92 & 1 & & & & & & & & & & \\
\hline $\mathrm{LN}$ & -0.92 & 0.91 & 0.85 & 1 & & & & & & & & & \\
\hline SR & -0.94 & 0.96 & 0.88 & 0.93 & 1 & & & & & & & & \\
\hline ADW & -0.91 & 0.90 & 0.82 & 0.99 & 0.93 & 1 & & & & & & & \\
\hline UDW & -0.86 & 0.85 & 0.77 & 0.99 & 0.89 & 0.99 & 1 & & & & & & \\
\hline MDA & 0.52 & -0.56 & -0.58 & -0.63 & -0.72 & -0.65 & -0.64 & 1 & & & & & \\
\hline SP & -0.76 & 0.65 & 0.56 & 0.81 & 0.68 & 0.84 & 0.84 & -0.32 & 1 & & & & \\
\hline Pro & 0.90 & -0.96 & -0.80 & -0.92 & -0.97 & -0.92 & -0.88 & 0.63 & -0.65 & 1 & & & \\
\hline Chl & -0.68 & 0.75 & 0.59 & 0.82 & 0.86 & 0.85 & 0.84 & -0.82 & 0.58 & -0.88 & 1 & & \\
\hline MP & 0.91 & -0.93 & -0.86 & -0.93 & -0.98 & -0.94 & -0.91 & 0.79 & -0.67 & 0.95 & -0.89 & 1 & \\
\hline $\mathrm{K}^{+} / \mathrm{Na}^{+}$ & -0.80 & 0.71 & 0.61 & 0.87 & 0.75 & 0.90 & 0.89 & -0.44 & 0.99 & -0.73 & 0.68 & -0.77 & 1 \\
\hline
\end{tabular}

SC - salt content, LL - leaf length, LW - leaf width, LN - leaf number, SR - survival rate, ADW - aboveground dry weight, UDW - underground dry weight, MDA - malonaldehyde, SP - soluble protein, Pro - proline, Chl - total chlorophyll, MP - membrane permeability, $\mathrm{K}+/ \mathrm{Na}+-$ ions rate 

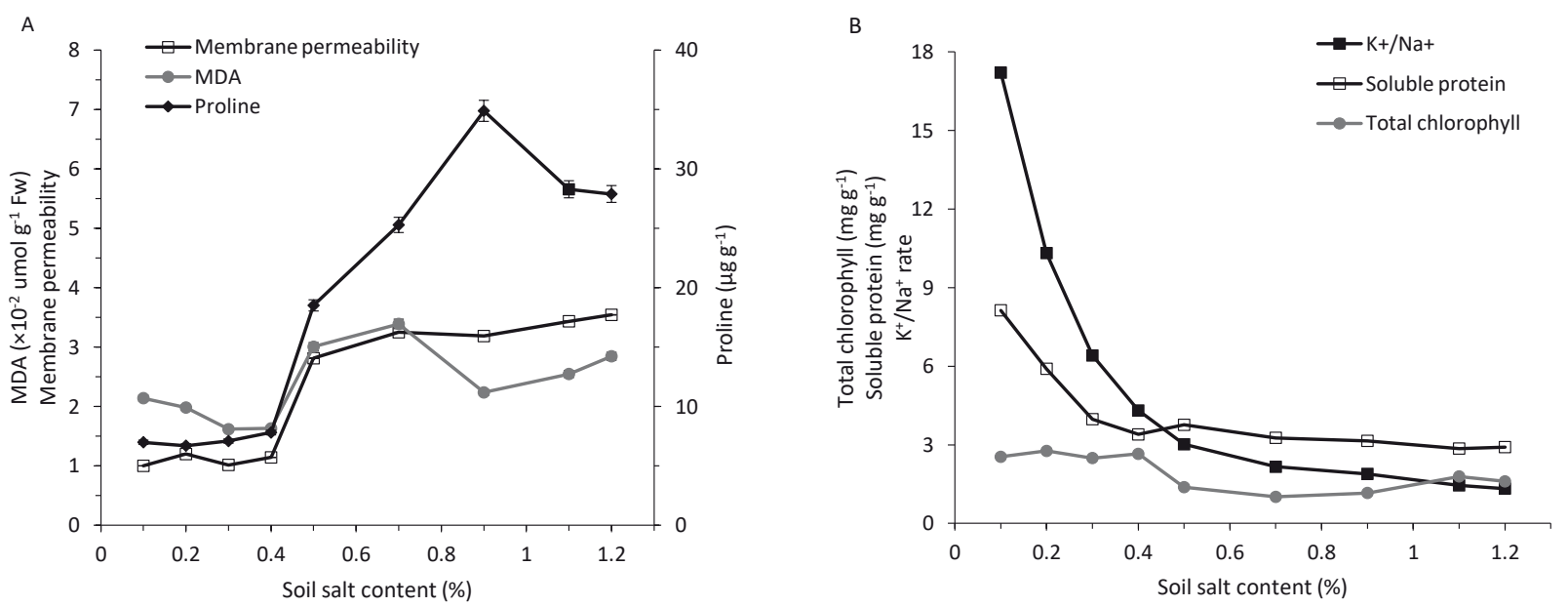

Figure 4. Physiological parameters of T. erythropodium under increasing soil salt content. Six repetitions with 25 measurement values for each treatment were used to calculate the means

leaflength, survival rate and aboveground dry matter weight as affected by soil salt content were 0.97 , 0.94 and 0.91 , respectively. However, the correlation coefficient between aboveground dry matter weight and leaf number was 0.99 . The purpose of this experiment was to study the aboveground yield of dandelion. Therefore, the aboveground dry matter weight was considered to be the morphological index for salt tolerance identification. Using the same method to analyze the correlation coefficients among the six physiological parameters of dandelion with respect to salt stress, it was found that the correlation coefficient between plasma membrane permeability and salt stress was 0.908 (Tab. 1). Therefore, plasma membrane permeability was considered as the physiological index for salt tolerance identification (Melillo, 2012).

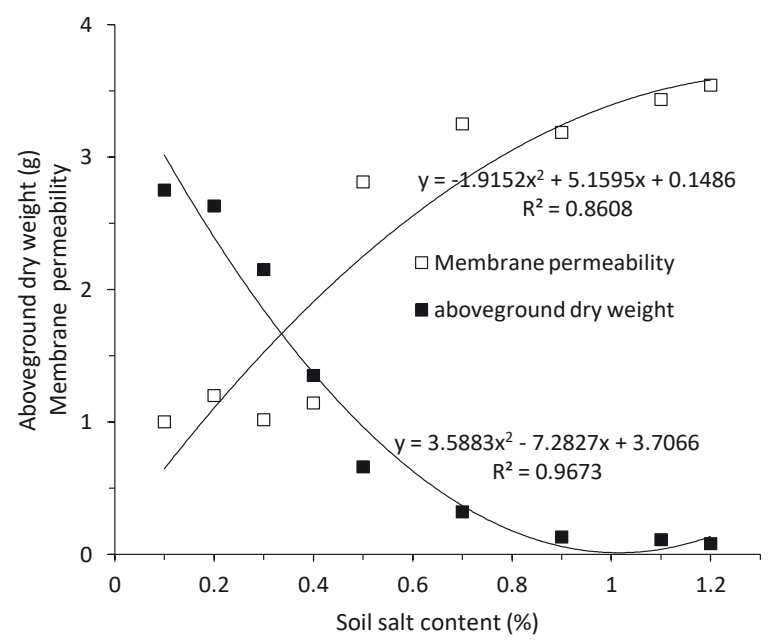

Figure 5. Regression analysis for the determination of the salt tolerance threshold. Six repetitions with 25 measurement values for each treatment were used to calculate the means
Subsequently, the relationships of aboveground dry matter weight and plasma membrane permeability with salt concentration were described in each case by a polynomial function, and two correlation equations were obtained (Fig. 5). When the soil salt content of $0.1 \%$ was used as the control, the salt tolerance thresholds obtained were $0.4 \%$ and $0.43 \%$, respectively, and these results were in agreement with the results of the experiment presented above (Figs 2 and 4).

\section{Fresh leaf yield and functional components under fertilizer control}

The results showed that leaf length, leaf number and yield increased with the increase in the fertilizer application rate. However, overly high or low fertilization was not conducive to the growth of dandelion (Tab. 2). The highest fresh yield was $10.5 \mathrm{t} \mathrm{ha}^{-1}$ when urea was applied at $162 \mathrm{~kg}$, $162 \mathrm{~kg}$ and $81 \mathrm{~kg} \mathrm{ha}^{-1}$ at the sowing, seedling and flowering stage, respectively. It should be noted that this yield was calculated based on the first batch harvested. Generally, this dandelion cultivar could be harvested 3-5 times for one year according to the cultivation practice, indicating that at least triple yields could be obtained within one year. Based on the highest fresh leaf yield under different $\mathrm{KH}_{2} \mathrm{PO}_{4}$ and urea application rates, it could be summarized that the favourable amount of fertilizer application could be converted to pure nitrogen of $123 \mathrm{~kg} \mathrm{ha}^{-1}$, $\mathrm{P}_{2} \mathrm{O}_{5}$ of $78 \mathrm{~kg} \mathrm{ha}^{-1}$ and $\mathrm{K}_{2} \mathrm{O}$ of $48 \mathrm{~kg} \mathrm{ha}^{-1}$, respectively. The phosphate fertilizer and potassium fertilizer were applied only once as basic fertilizers, while the nitrogen fertilizer was applied at three stages, with the rate varied at a ratio of 2:2:1 for the sowing stage : seedling stage : flowering stage. 
Table 2. Yield and growth parameters of dandelion grown on saline land under different urea application rates

\begin{tabular}{rcccccccc}
\hline \multicolumn{1}{c}{ I } & II & III & LN & LL & LW & PW & FLY & DLY \\
\hline $\mathrm{kg} \mathrm{ha}^{-1}$ & $\mathrm{~kg} \mathrm{ha}^{-1}$ & $\mathrm{~kg} \mathrm{ha}^{-1}$ & $\mathrm{~cm}$ & $\mathrm{~cm}$ & $\mathrm{~cm}$ & $\mathrm{~cm}$ & $\mathrm{~kg} \mathrm{ha}^{-1}$ & $\mathrm{~kg} \mathrm{ha}^{-1}$ \\
\hline 0 & 0 & 0 & $11.2 \pm 0.4^{\mathrm{a}}$ & $21.6 \pm 0.6^{\mathrm{a}}$ & $6.5 \pm 0.2^{\mathrm{a}}$ & $37.4 \pm 1.9^{\mathrm{a}}$ & $6615 \pm 292^{\mathrm{a}}$ & $885 \pm 40^{\mathrm{a}}$ \\
54 & 54 & 27 & $12.4 \pm 0.5^{\mathrm{b}}$ & $22.0 \pm 0.5^{\mathrm{a}}$ & $7.0 \pm 0.2^{\mathrm{a}}$ & $38.2 \pm 2.0^{\mathrm{a}}$ & $6465 \pm 272^{\mathrm{a}}$ & $870 \pm 38^{\mathrm{a}}$ \\
108 & 108 & 54 & $12.9 \pm 0.5^{\mathrm{bc}}$ & $24.2 \pm 0.5^{\mathrm{b}}$ & $7.5 \pm 0.3^{\mathrm{a}}$ & $44.0 \pm 1.6^{\mathrm{b}}$ & $8250 \pm 366^{\mathrm{b}}$ & $1005 \pm 37^{\mathrm{b}}$ \\
162 & 162 & 81 & $13.9 \pm 0.6^{\mathrm{d}}$ & $23.9 \pm 0.5^{\mathrm{b}}$ & $7.3 \pm 0.3^{\mathrm{a}}$ & $43.3 \pm 1.5^{\mathrm{b}}$ & $10545 \pm 423^{\mathrm{c}}$ & $1350 \pm 51^{\mathrm{c}}$ \\
216 & 216 & 108 & $13.4 \pm 0.5^{\mathrm{cd}}$ & $25.2 \pm 0.5^{\mathrm{c}}$ & $7.4 \pm 0.3^{\mathrm{a}}$ & $45.2 \pm 1.4^{\mathrm{b}}$ & $8250 \pm 337^{\mathrm{b}}$ & $990 \pm 42^{\mathrm{b}}$ \\
\hline
\end{tabular}

Different urea application rates in stages I, II and III, which represent the beginning stage, seedling stage and blooming stage, respectively. $\mathrm{KH}_{2} \mathrm{PO}_{4}$ was the basic fertilizer and $225 \mathrm{~kg} \mathrm{ha}^{-1}$ was applied in each treatment in stage I. Within columns, means followed by the same letter are not significantly different according to Duncan's (D) significant difference test $(p<0.05)$. Values represent the means of each treatment \pm standard error, which were calculated from 75 measurement values in three repetitions. LL - leaf length, LW - leaf width, LN - leaf number, PW - plant width, FLY - fresh leaf yield, DLY - dry leaf yield

The fresh leaf yield and functional components of five other dandelion species were compared under the strategy of salt-washing treatment and fertilizer application (Tab. 3). Except for the flavonoid content, the fresh leaf yield and the chlorogenic acid and selenium contents of the cultivar Daye were significantly higher than those of the other five species, indicating that a high leaf yield and acceptable quality of this dandelion cultivar could be obtained by cultivation on coastal saline land based on the control of salinity and fertilizer.

\section{DISCUSSION}

The significance of the salt tolerance threshold indicated that the yield of dandelion would be seriously decreased if the salt content went over the threshold. The salt tolerance threshold in the current research ranged from $0.4 \%$ to $0.43 \%$, which was consistent with the previous study (Liu et al., 2017). However, the value of the salt tolerance threshold is not invariable; it depends on different identification methods and cultivation periods (Abbasi et al., 2016; Liu et al., 2017). The salt tolerance threshold in the current research corresponded to the result of salt tolerance identification at the seedling stage for one-year cultivation, which was not applicable to the later growth stages according to the observation on the $90^{\text {th }}$ day that the salt tolerance ability of dandelion plants in all the treatments was enhanced and their growth did not show significant differences when the salt content ranged from $0.1 \%$ to $0.7 \%$. The enhanced salt tolerance ability was probably due to the enlarged root system, which improved salt tolerance (Muchate et al., 2016). The salt tolerance of dandelion was continuously observed for 90 days, and it was found that the limit of salt tolerance was $1.0-1.1 \%$, which was far higher than for common vegetables such as cabbage, tomato, and cucumber (Cao et al., 2013). By comparison, the reported salt tolerance limit of dandelion ranged from $0.7 \%$ to $0.9 \%$ according to the traditional salt tolerance identification method (Liu et al., 2017).

The traditional method of salt tolerance identification is to irrigate with salt water directly, and then check the morphological and physiological indicators (Parida and Das, 2005; Muchate et al., 2016). However, the shortcoming is that repeated irrigation with saline water would lead to salt

Table 3. Functional components and yield of dandelion cultivars on saline land

\begin{tabular}{|c|c|c|c|c|}
\hline Habitat and species name & $\begin{array}{l}\text { Flavonoids } \\
\left(\mathrm{mg} 100 \mathrm{~g}^{-1}\right)\end{array}$ & $\begin{array}{c}\text { Selenium } \\
\left(\mathrm{mg} 100 \mathrm{~g}^{-1}\right)\end{array}$ & $\begin{array}{l}\text { Chlorogenic } \\
\text { acid } \\
\left(\mathrm{mg} 100 \mathrm{~g}^{-1}\right)\end{array}$ & $\begin{array}{c}\text { Fresh leaf } \\
\text { yield } \\
\left(\mathrm{t} \mathrm{ha}^{-1}\right)\end{array}$ \\
\hline Anguo (Taraxacum sinicum) & $0.45 \pm 0.018^{\mathrm{a}}$ & $7.6 \pm 0.28^{b}$ & $43.7 \pm 1.87^{\mathrm{c}}$ & $7.8 \pm 0.45^{\mathrm{a}}$ \\
\hline Tangshan (Taraxcum erythropodium) & $0.87 \pm 0.010^{\mathrm{e}}$ & $8.3 \pm 0.30^{\mathrm{c}}$ & $46.6 \pm 1.78^{\mathrm{d}}$ & $8.8 \pm 0.54^{\mathrm{b}}$ \\
\hline Shenyang (Taraxacum officinale) & $0.86 \pm 0.011^{\mathrm{e}}$ & $7.6 \pm 0.26^{\mathrm{b}}$ & $43.6 \pm 1.90^{c}$ & $9.2 \pm 0.56^{\mathrm{b}}$ \\
\hline Daye (Taraxacum erythropodium) & $0.66 \pm 0.019^{\mathrm{d}}$ & $8.9 \pm 0.32^{\mathrm{d}}$ & $48.7 \pm 1.87^{\mathrm{e}}$ & $10.5 \pm 0.64^{\mathrm{c}}$ \\
\hline Handan (Taraxacum sinicum) & $0.48 \pm 0.010^{\mathrm{b}}$ & $7.9 \pm 0.29^{b}$ & $39.6 \pm 1.06^{\mathrm{b}}$ & $8.4 \pm 0.54^{\mathrm{ab}}$ \\
\hline Zhangjiakou (Taraxacum mongolicum Hand.-Mazz.) & $0.63 \pm 0.014^{\mathrm{c}}$ & $4.6 \pm 0.22^{\mathrm{a}}$ & $28.9 \pm 1.46^{\mathrm{a}}$ & $8.5 \pm 0.61^{\mathrm{ab}}$ \\
\hline
\end{tabular}

Within columns, means followed by the same letter are not significantly different according to Duncan's (D) significant difference test $(p<0.05)$. Values represent the means of each treatment \pm standard error, which were calculated from 25 measurement values in six repetitions 
accumulation, resulting in an uneven distribution of water and salt. Therefore, it is difficult to conclude whether the changes in growth performance are caused by salt stress (Golldack et al., 2014). The salt tolerance identification method in the current research ensured a uniform distribution of water and salt through automatically absorbing the water itself, which made the salt tolerance identification results repeatable and reliable. Therefore, the improvement in the salt-tolerance limit of dandelion in the current research may be due to the stable distribution of water and salt in the current salt-tolerance identification method. In addition, considering the drought conditions in the field, the range of salt tolerance threshold was adjusted to $0.3-0.4 \%$ as the standard to guide dandelion sowing on saline-alkaline land.

Dandelion leaves were the main part absorbing $\mathrm{K}^{+}$and $\mathrm{Na}^{+}$. The processes of absorption of $\mathrm{K}^{+}$and $\mathrm{Na}^{+}$compete with each other; $\mathrm{Na}^{+}$often enters cells through the $\mathrm{K}^{+}$pathway, so the $\mathrm{K}^{+} / \mathrm{Na}^{+}$rate could reflect the effect of salt stress on plants to some extent (Abbasi et al., 2016). In a previously published work, it had been found that the accumulation of $\mathrm{Na}^{+}$in the leaves increased significantly with the increase in soil salt content, which eventually led to a decrease in the $\mathrm{K}^{+} / \mathrm{Na}^{+}$rate (Liu et al., 2017). $\mathrm{K}^{+}$is a macroelement and osmotic regulator necessary for plant growth and development, and it is also a cation that plants need to be present in high concentrations (Abbasi et al., 2016). Therefore, higher $\mathrm{K}^{+} / \mathrm{Na}^{+}$ratios could alleviate the injury of salt stress on dandelion. And thus, when applying a fertilizer, $\mathrm{KH}_{2} \mathrm{PO}_{4}$ fertilizer was used as the basic fertilizer in order to increase the $\mathrm{K}^{+}$content around the root system and reduce the toxicity of $\mathrm{Na}^{+}$to the root.

This research studied the cultivation of a highyielding dandelion cultivar on saline-alkaline land, and the fresh leaf yield obtained ranged from 6.6 to 10.5 tha $^{-1}$, which was similar to the results of research by Kreuzberger et al. (2016) based on different planting densities. However, the planting density of 220,000 plants $\mathrm{ha}^{-1}$ in the current research was only half of that in Kreuzberger's research. And the soil nutrition on the coastal saline land was also lower than that land conditions in Kreuzberger's research. The results also showed that leaf yield increased with the increase in the fertilizer application rate. Due to poor soil conditions, the cattle manure and chemical fertilizers were applied to promote dandelion production. However, excessive fertilization could lead to energy waste and pollution, and also affect the effective compounds in the plants (Melillo, 2012). Some studies have reported that the application of an organic fertilizer could enhance the production of total phenolics and flavonoids in Labisia pumila, besides the fact that the application of nitrogen improved its production of secondary metabolites (Ibrahim et al., 2013; Shiwakoti et al., 2016). In the current research, the functional components of dandelion plants from different habitats showed that the cultivar 'Daye' was relatively rich in chlorogenic acid and selenium, but had a lower flavonoid content than the other dandelion species. This may be related to the relatively low application rate of $\mathrm{KH}_{2} \mathrm{PO}_{4}$ and the saline silty soil limiting the release of $\mathrm{K}^{+}$ (Shiwakoti et al., 2016). The current research work showed that it was feasible to plant dandelion on saline-alkaline land and obtain high yields, but how to take into account fertilizer application, yield and quality still needs to be studied further.

\section{CONCLUSIONS}

In conclusion, the dandelion (Taraxacum erythropodium) 'Daye' cultivar has a strong salttolerance ability and can be cultured on saline land for vegetable production. The salt tolerance evaluation of dandelion guided the saline land treatment through salt-washing based on the salt tolerance threshold for dandelion field cultivation. The proper fertilizer application management was favourable for increasing leaf yield and the amounts of functional components of dandelion grown on saline land.

\section{ACKNOWLEDGEMENTS}

The authors wish to thank for the support from the Institute of Coastal Agriculture, Hebei Academy of Agriculture and Forestry Sciences, Tangshan, China, and also thank for the assistance by Miss Yaru ning, Miss Promsap Duangmanee and Mr. Zhaojia Li.

\section{FUNDING}

This research was supported by the HAAFS Agriculture Science and Technology Innovation Project (F18R18001); Hebei key research and development plan (18227121D); Overseas talent introduction funding programme (C201842); Tangshan Sci \&Tech research plan (18120206A); Shijiazhuang Sci \&Tech research plan (197490184A); Hebei technology innovation guidance project (19826902D). 


\section{AUTHOR CONTRIBUTIONS}

Z.W. - was involved in data analysis and manuscript writing; X.W. - designed the research; Z.X, X.Z and H.L. - reviewed the manuscript and provided the materials; X.L. - reviewed the manuscript and wrote the paper.

\section{CONFLICT OF INTEREST}

The authors declare no conflict of interest.

\section{REFERENCES}

Abbasi H., Jamil M., Haq A., Ali S., Ahmad R., Malik Z., ET AL., 2016. Salt stress manifestation on plants, mechanism of salt tolerance and potassium role in alleviating it: a review. Zemdirbyste 103, 229-238.

Arias M., Hernández M., Ritter E., 2016. How does water supply affect taraxacum koksaghyz rod. rubber, inulin and biomass production? Ind. Crop. Prod. 91, 310-314.

Cao L., Wang Y.F., Chen B.Y., Wang Q., 2013. The comparison of salt tolerance in major vegetable crops. Acta Agric. Boreali-Sin. 28, 233-237.

Clemens S., 2017. Plant Physiology and Function. Springer, New York, USA.

Eggert M., Schiemann J., Thiele K., 2018. Yield performance of Russian dandelion transplants (Taraxacum koksaghyz L. Rodin) in flat bed and ridge cultivation with different planting densities. Eur. J. Agron. 93, 126-134.

Golldack D., Li C., Mohan H., Probst N., 2014. Tolerance to drought and salt stress in plants: Unraveling the signaling networks. Front. Plant Sci. 5,151 .

IBRAHIM M.H., JAAFAR H.Z., KARIMI E., GHASEMZADEH A., 2013. Impact of organic and inorganic fertilizers application on the phytochemical and antioxidant activity of kacip fatimah (Labisia pumila Benth). Molecules 18, 10973-10988.

IDDRISU I., Oduro I., TANDOH M., 2016. The effect of dandelion leaves and roots on blood glucose in type 2 diabetic patients. J. Nutr. Ecol. Food Res. 3, 125132.

Jiang J.Y., Yang W.Z., Kang C.Z., Liu Y.H., Sheng W., KAI S., ET AL., 2018. Assessment of soil fertility for cultivation of Chinese herbal medicines. China J. Chin. Materia Med. 43, 847-852.

Katrin S., Dietmar RK., Reinhold C., Andreas S., 2010. Characterization of phenolic acids and flavonoids in dandelion (Taraxacum officinale WEB. ex WIGG.) root and herb by high-performance liquid chromatography/electrospray ionization mass spectrometry. Rapid Commun. Mass Spectrom. 19, 179-186.
Kreuzberger M., Hahn T., Zibek S., Schiemann J., Thiele K., 2016. Seasonal pattern of biomass and rubber and inulin of wild Russian dandelion (Taraxacum koksaghyz L. Rodin) under experimental field conditions. Eur. J. Agron. 80, 66-77.

KuUsi T., HÅrdH K., KanON H., 1984. Experiments on the cultivation of dandelion for salad use. I. Study of cultivation methods and their influence on yield and sensory quality. Agr. Food Sci. 56, 9-22.

Li X., Kang Y., Wan S., Chen X., Liu S., Xu J., 2016. Response of a salt-sensitive plant to processes of soil reclamation in two saline-sodic, coastal soils using drip irrigation with saline water. Agr. Water Manage. 164, 223-234.

Liu Y., Wang X., Zuo Y., Zhang G., Lu X., 2017. Response of dandelion to saline stress and determination of salt-tolerance threshold at seedling stage. Acta Agric. Boreali-Occident. Sin. 26, 12231229.

Melillo E.D., 2012. The first green revolution: debt peonage and the making of the nitrogen fertilizer trade, 1840-1930. Am. Hist. Rev. 117, 1028-1060.

Muchate N.S., Nikalje G.C., Rajurkar N.S., SupRasAnNA P., NiKAM T.D., 2016. Plant salt stress: adaptive responses, tolerance mechanism and bioengineering for salt tolerance. Bot. Rev. 82, 371406.

PARIDA A.K., DAs A.B., 2005. Salt tolerance and salinity effects on plants: a review. Ecotox. Environ. Safe. 60, 324-349.

Shiwakoti S., Shannon D.A., Wood C.W., Joshee N., Rimando A., LaWrence K.S., At AL., 2016. Nitrogen, phosphorus and potassium effects on biomass yield and flavonoid content of American Skullcap (Scutellaria lateriflora). J. Plant Nutr. 39, 1240-1249.

Wang Y.R., YA-Meng L.I., YAng N., Zhou B.S., Chen F., LiU J.P., ET AL., 2017. Research progress on chemical compositions and pharmacological actions of taraxacum. Special Wild Eco. Animal. Plant Res. 39, 67-75.

Xiuping W., Zhizhong X., Xuelin L., Yahui L., GuANGMing L., ZHE W., 2019. Salt leaching of heavy coastal saline silty soil by controlling the soil matric potential. Soil Water Res. 3, 132-137.

Xuelin L., Zhe W., Xiuping W., Xiaodong Z., Yongmei Z., 2019. Research on the cultivation technology for the dandelion in saline-alkali land. Anhui Agric. Sci. Bull. 25, 63-65, 160.

Zhang X., Chen X., JiAng D., Li Y., 2008. Selection and characterization of salt-tolerant calli of Taraxacum officinale. Chin. J. Biotechnol. 24, 1202-1209.

Received April 2, 2019; accepted July 8, 2019 